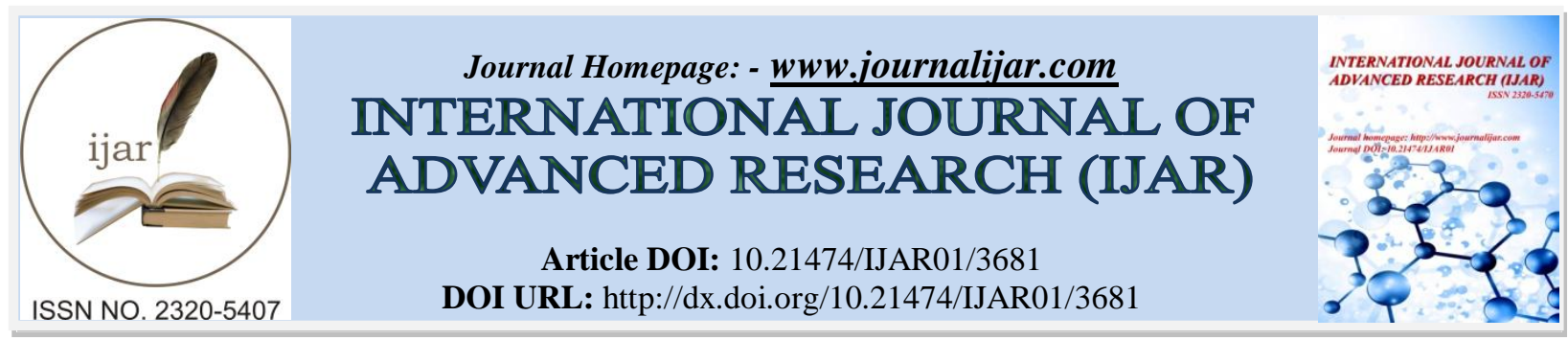

RESEARCH ARTICLE

\title{
IMPACTS OF FLOOD AND ITS MANAGEMENT - A CASE STUDY OF BIHAR.
}

Mitthan Lal Kansal $^{1}$, Kumar Abhishek Kishore ${ }^{2}$ and Prashant Kumar ${ }^{2}$.

1. Professor, Deptt. of Water Resources Development \& Management, IIT Roorkee, Roorkee-247667 India.

2. PG Student, Deptt. of Water Resources Development \& Management, IIT Roorkee, Roorkee-247667 India.

\section{Manuscript Info}

Manuscript History

Received: 12 January 2017

Final Accepted: 07 February 2017

Published: March 2017

Key words:-

Floods in Bihar, Kosi, Flood Impacts, Flood Management, Structural and Nonstructural Measures.

\begin{abstract}
Floods are most recurring and frequent natural hazard in India causing enormous loss to life and livelihood, and damage to infrastructure. In India, Bihar is one of the worst affected states due to floods. As per one estimate, in Bihar flood affects about 6.880 million hectares of land out of about 9.416 million hectare, which is about $73.06 \%$. It not only affects the infrastructure but also the socio-economic life in the state. So, there is a need to minimize negative consequences and ill effects of flooding by means of flood management. In Bihar, most of the times, the decision makers go for structural measures like construction of embankments, flood retention walls, flood levees and channel improvements, etc. However, it is felt that structural measures itself is not sufficient to reduce the adverse impacts of floods in the state. Hence non-structural measures like flood plain management policy, building bye-laws, flow and silt management policy are also required. It contemplates the use of flood plains judiciously, simultaneously permitting vacating of the same for use by the river whenever the situation demands. The purpose of this paper is to highlight the severity of flood impacts on development of state and to discuss the possible flood management measures in context of Bihar.
\end{abstract}

Copy Right, IJAR, 2017,. All rights reserved.

\section{Introduction:-}

Floods have been a recurrent phenomenon in India causing huge losses to lives, properties, livelihood systems, infrastructure and public utilities affecting the development of the region. Bihar is one of the States of the India bounded by Nepal in the north. Main drainage system of the state, the River Ganga flow eastward direction in a stretch of $432 \mathrm{~km}$ across Bihar and divides the state in two unequal halves. The plains in north of the River Ganga are drained by two major rivers, the River Kosi and the Gandak (Fig.1). In addition to this there are several smaller systems such as the Adhwara group of rivers, the Bagmati, the Bhutahi Balan, the Burhi Gandak, the Ghaghara, the Kamala, and the Mahananda. All these rivers mainly originate in Nepal from the Himalayas whereas the River Kosi also includes its catchment in Tibet. Thus, the rivers of North Bihar mostly share basins outside the country in Nepal and Tibet. The water carried from the part of catchment lying in Tibet also passes through Nepal. To fulfil the requirement of fuel for domestic purposes and reclamation of area for occupational needs, there is an increasing deforestation in Nepal which further causes degradation in vegetative cover in the catchment areas. Due to this practice, soil has been increasingly getting eroded from these areas. So the rivers carries significant sediment load from the upper part of catchments. These sediments in addition to inadequate carrying capability of the rivers cause congestion in natural drainage leading to inundation and floods. So, flood is a state of hydrological extreme of high 
water level in a stream channel or on bank that results in inundation of land that isn't ordinarily submerged. Generally it occurs in event of heavy rainfall and becomes a hazard once it causes loss to the lives, livestock and livelihood. "The trend shows that the intensity and frequency of floods in Bihar Plains have increased over the years causing human suffering and destruction of agriculture, habitation and infrastructure" (NIDM, 2007).

The National Flood Commission, set by Government in 1976 put the country's flood prone area at about 40 MHa out of total area of 329 MHa. This report, thus, revealed a rapid increase in flood proneness in just over a decade. Most of these area falls under Ganga and Brahmaputra basins. The most flood prone basins are those of the Ganga and Brahmaputra in Uttar Pradesh, Bihar, West Bengal and Assam. These five states are the most flood prone. But the commission analyzed the share of damage went up from 25 to 50 percent of the total and chronically flood prone area in case of Bihar.

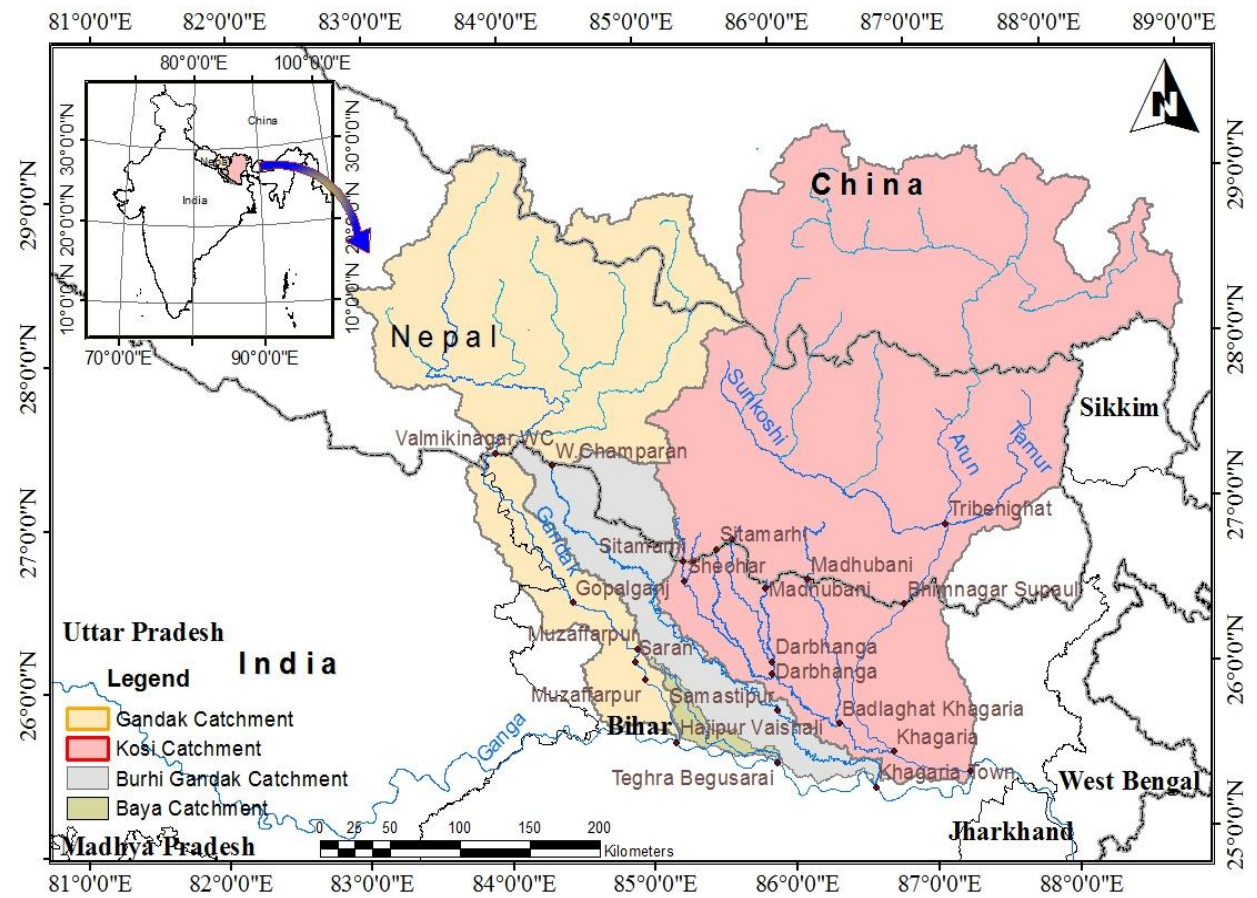

Figure 1:- Map Showing Catchment of Major Rivers in North Bihar

Three fourths area and population of Bihar lie in the natural flood plains of the Ganga and its Himalayan tributaries. About 6.880 out of 9.416 million hectare comprising 73.06 percent of the state is flood affected which accounts for approximately one-sixth of the flood prone area in India. Geographically, northern Bihar is prone to flood as major rivers flowing through North Bihar originates from Nepal and the Tibetan region of China. About $65 \%$ of the catchment area of Bihar's rivers fall in Nepal and Tibet and only 35\% of the catchment areas lie in Bihar (Sinha et. al.).

The upper part of catchment is liable for the morphological activities within the downstream reaches. It carries huge sediment load with its flow every year which is responsible for change in morphological behaviour of the stream. The matter of the flooding is implicitly guided by sedimentation in river. This sedimentation has gradually reduced the capability of the river to drain extreme flows leading to flooding within the plains.

The variation of minimum and the maximum flows in the Himalayan Rivers is significantly high. This causes huge seasonal variation in river discharge. In addition to this terrain of North Bihar is almost flat having elevation at Indo-Nepal border ranging from 90-95 m whereas elevation at confluence of these rivers in Ganga is of the order of 40-45m.

So, Vulnerability to flood of Bihar lies in its flat topography, wide variation in flow in Himalayan rivers, excessive rainfall levels (more than $1200 \mathrm{~mm}$ annually), annual rainfall concentration during only three monsoon months and high sediment loads. The plains of Bihar and adjoining Nepal are drained by rivers that carry high discharge and very high sediment loads, which then fall out onto the plains of Bihar. "Gradients vary from $22 \mathrm{~cm}$ per km near the 
Indo-Nepal boundary to $7.5 \mathrm{~cm}$ per $\mathrm{km}$ near the confluence of the rivers with the Ganga main stem" (Sinha et. al., 2012). The flat terrain and the major seasonal variations in water volume in the rivers cause extensive flooding in the northern plains. In addition, as the rivers reach the plains and lose momentum, they begin to meander. Rivers like the Kosi are notorious for changing course. "As per the records it is evident that during 1736 to 1953 the river Kosi has shifted its course through a distance of approximately $112 \mathrm{Km}$. towards westward” (Kumar D., 2015) (Fig.2). Further Kosi embankment was constructed with a series of spurs on both banks confining the course of river Kosi.

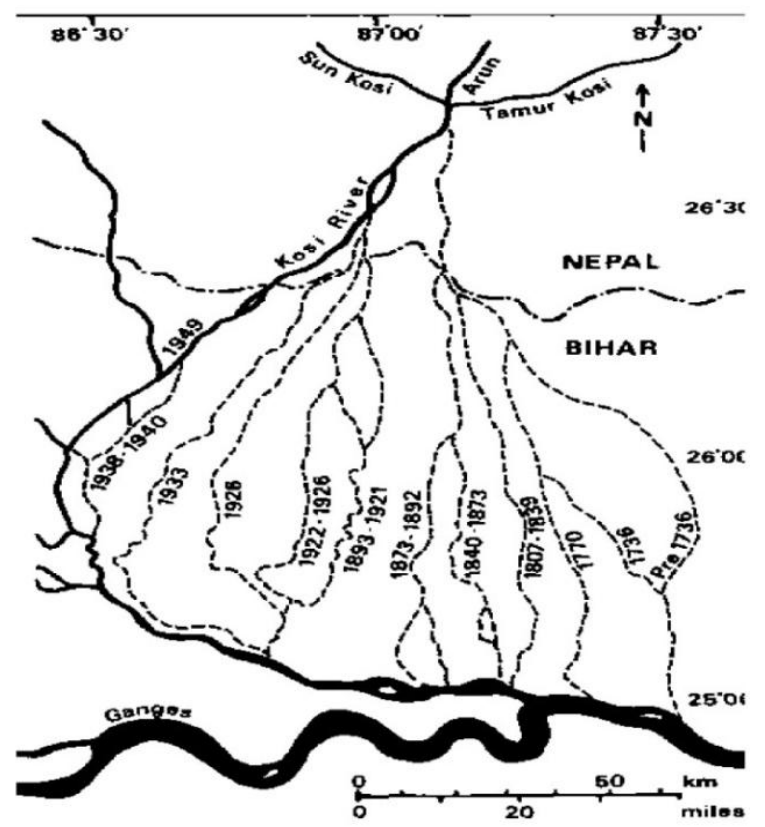

(Source: Kumar D., 2015)

Figure 2:- Kosi River Course.

The embankments on both sides spaced five to sixteen $\mathrm{km}$ apart have confined the lateral shift of the river within the embankments; however flooding is still a challenge in the area. Human intervention in the flood plain is also making this problem more acute.

\section{Impacts of Flood:-}

Flood impacts can be broadly divided into primary impact that occur due to contact with water like loss of life, livestock and property, damage caused to infrastructures like road, bridges, railways, disruption in services like electricity, telephone lines, water supply lines, etc. and secondary impact that occur because of the flooding, such as disruption of services, prolonged health and malnutrition impacts. Secondary impacts cause indirect losses and its ill effect continues on-long time scales and sometimes may be more important. These include prolonged health impacts due to failure of water supply and sewage disposal system, shortage of food and other essentials due to failure in transportation network. A frame work of flood impacts is shown in fig. 3.

Infrastructure networks sustain various activities and services of the communities and industries. Due to failure of services from damaged infrastructure economic activities in the region are also poorly affected. It may lead to partially or completely shut down of industries and business establishments causing reduced production followed by adverse impact on economic growth. There may be some long term impacts like sediment deposited by flooding may destroy farm land for coming few years leading to cultivator and labours economically vulnerable. Based on the assessment of losses in monetary values, they are termed as tangible if can be assessed in terms of monetary values and if not then termed as intangible losses. Intangible losses are generally higher in less developed region because of the more consequences of flooding especially in case of frequent and devastating floods.

"Impacts of flood depend on maximum depth and duration of flooding, the extent of inundation in the floodplains, velocity of flow and rate of rise of flood levels" (Gautam et al.). Flash flood causes immediate and huge impacts, whereas gradually occurring floods allows much time for evacuation and protection of properties. 


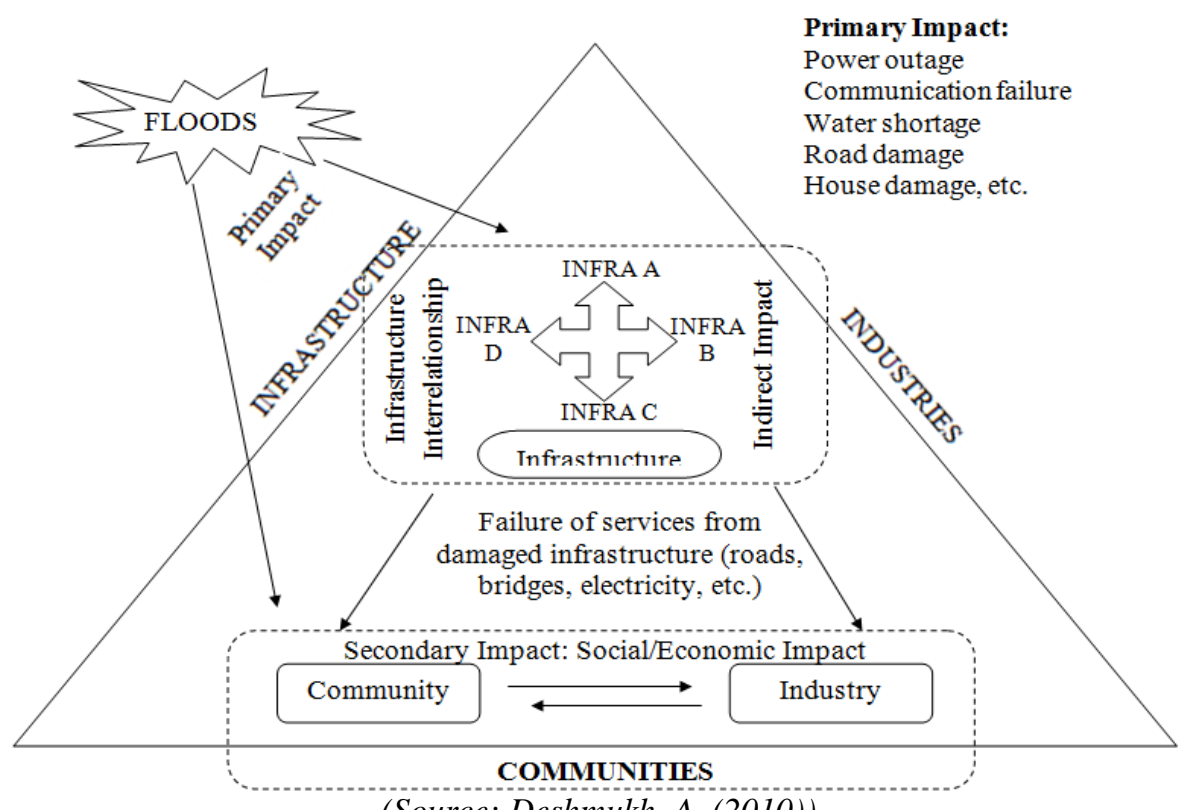

(Source: Deshmukh, A. (2010))

Figure 3:- Framework of Flood Impacts.

Flood Losses in Bihar:-

Almost every year floods severely damages property, both movable and immovable, destroys standing crops and food grains and badly cripples the infrastructure in Bihar. The loss of life and limb caused due to flood events cannot be compensated. However in monetary values, it costs several crores every year. The flood brings untold miseries to the people as they have to leave their damaged houses and spend a long time in relief camps, raised platforms or in temporary shelters. Government has to allocate huge amount for rehabilitation, and relocation of people which requires diversion of capital required for maintaining production. Table 1 shows the extent of flood loss in Bihar for last 15 years.

Table.1:- Flood losses in Bihar from 2000 to 2015.

\begin{tabular}{|c|c|c|c|c|c|c|c|c|c|c|c|c|}
\hline \multirow{3}{*}{ Year } & \multirow{3}{*}{$\begin{array}{l}\text { River which } \\
\text { caused flood }\end{array}$} & \multicolumn{5}{|c|}{ Number of Affected } & \multicolumn{2}{|c|}{ Affected Area } & \multicolumn{2}{|c|}{ House Damaged } & \multicolumn{2}{|c|}{ Loss } \\
\hline & & Dist. & Block & Vill. & Human & Animal & Agric & $\begin{array}{l}\text { Non- } \\
\text { Agric }\end{array}$ & Fully & Partly & Live & $\begin{array}{l}\text { Live- } \\
\text { stock }\end{array}$ \\
\hline & & \multicolumn{3}{|c|}{ (Nos.) } & \multicolumn{2}{|c|}{ (in Lac) } & \multicolumn{2}{|c|}{ (Million ha.) } & \multicolumn{2}{|c|}{ (Nos.) } & \multicolumn{2}{|c|}{ (Nos.) } \\
\hline 2015 & Gandak, Kosi & 8 & 32 & 237 & 4.850 & 0.140 & 0.0090 & 0.0030 & 157 & 12 & 27 & 1 \\
\hline 2014 & Gandak & 20 & 116 & 2018 & 30.000 & 1.000 & 3.6000 & 0.3000 & 3235 & 2977 & 158 & 34 \\
\hline 2013 & Gandak, Kosi & 20 & 126 & 4810 & 72.340 & 5.600 & 1.6800 & 0.6900 & 9344 & 117572 & 253 & 6480 \\
\hline 2012 & Gandak, Ganga & 11 & 28 & 277 & 2.400 & 0.080 & 0.0968 & 0.0100 & 322 & 151 & 15 & 0 \\
\hline 2011 & Ganga & 25 & 166 & 3577 & 71.430 & 6.627 & 3.5420 & 0.2877 & 25840 & 59342 & 249 & 183 \\
\hline 2010 & Kosi & 9 & 44 & 679 & 7.180 & 3.570 & 0.1602 & 0.0390 & 6187 & 8983 & 32 & 0 \\
\hline 2009 & Bagmati, Gandak & 16 & 91 & 1546 & 22.030 & 1.346 & 0.1710 & 0.9339 & 3867 & 3807 & 97 & 2 \\
\hline 2008 & Kosi & 18 & 116 & 2585 & 49.952 & 12.166 & 0.6405 & 0.2119 & 104965 & 151461 & 258 & 878 \\
\hline 2007 & Gandak, Kosi & 22 & 269 & 18832 & 244.420 & 27.130 & 1.3323 & 0.5510 & 369360 & 414968 & 1287 & 2423 \\
\hline 2006 & Bagmati, Ganga & 14 & 63 & 959 & 10.890 & 0.100 & 0.1520 & 0.0297 & 9218 & 9419 & 36 & 31 \\
\hline 2005 & Bagmati, Gandak & 12 & 81 & 1464 & 21.040 & 5.350 & 0.3343 & 0.1261 & 1031 & 4507 & 58 & 4 \\
\hline 2004 & Gandak, Bhutahi & 20 & 211 & 9346 & 212.990 & 86.860 & 2.0990 & 0.6010 & 361017 & 568756 & 885 & 3272 \\
\hline 2003 & Gandak, Ganga & 24 & 172 & 5077 & 76.020 & 11.960 & 0.9943 & 0.5140 & 43163 & 41261 & 251 & 108 \\
\hline 2002 & Bagmati, Kamala & 25 & 6 & 8318 & 160.180 & 52.510 & 1.4446 & 0.5244 & 89021 & 329993 & 489 & 1450 \\
\hline 2001 & Gandak, Kosi, & 22 & 194 & 6405 & 90.910 & 11.700 & 0.9042 & 0.2910 & 128419 & 93589 & 231 & 565 \\
\hline 2000 & Kosi & 33 & 213 & 12351 & 90.180 & 8.090 & 0.6570 & 0.1476 & 183670 & 159421 & 336 & 2568 \\
\hline
\end{tabular}

(Source: Disaster Management Department, GoB) 


\section{Flood Impacts on Growth of Bihar:-}

Bihar is one of the states in India whose economy largely depends either on agriculture or in agricultural activities. It's share in Net State Domestic Product (NSDP) of Bihar is $29.33 \%$ which is considerably higher in comparison to contribution in national GDP which is $20.06 \%$ (Central Statistical Organisation, Govt. of India, 2014) (Fig.4(a) and 4(b)).

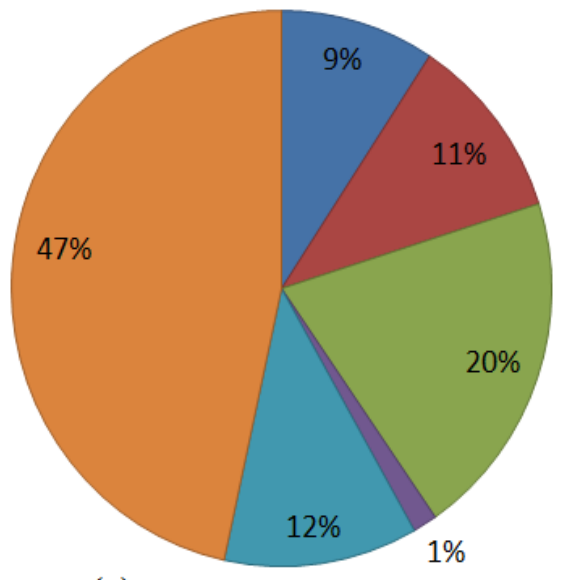

(a) agriculture

- Agriculture allied Services

$\square$ Industry

Mining and Quarrying

Manufacturing

$\square$ Services

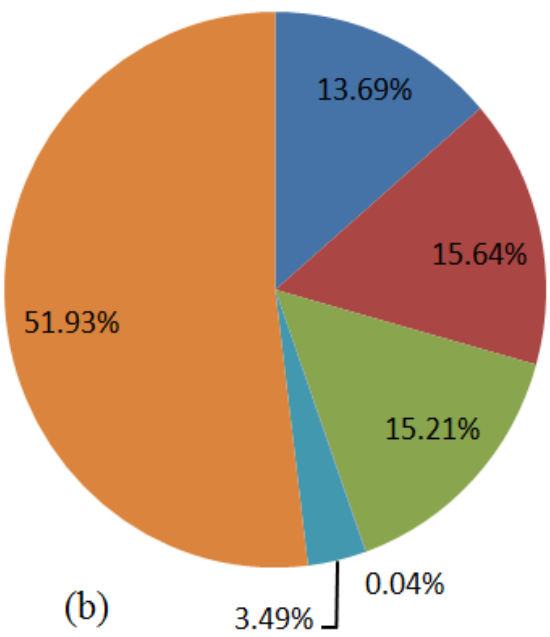

(Source: Directorate of Statistics and Economics, Bihar)

Figure 4:- (a) Share of various sectors in India's GDP (b) Share of various sectors in NSDP of Bihar.

Beside this fact, about $78 \%$ of population are involved in agriculture and its allied activities either as cultivator or agricultural labour (Fig.5(a)). According to government of Bihar 73\% of the farmers are small and marginal farmers, who not only cultivate their land but serves as agricultural labour. The situation is more vulnerable in the region of North Bihar with large flood prone area (Fig.5(b)). So, agriculture is the backbone of Bihar's economy and socioeconomic status. Hence sustainable development of Bihar principally depends upon agriculture sector.
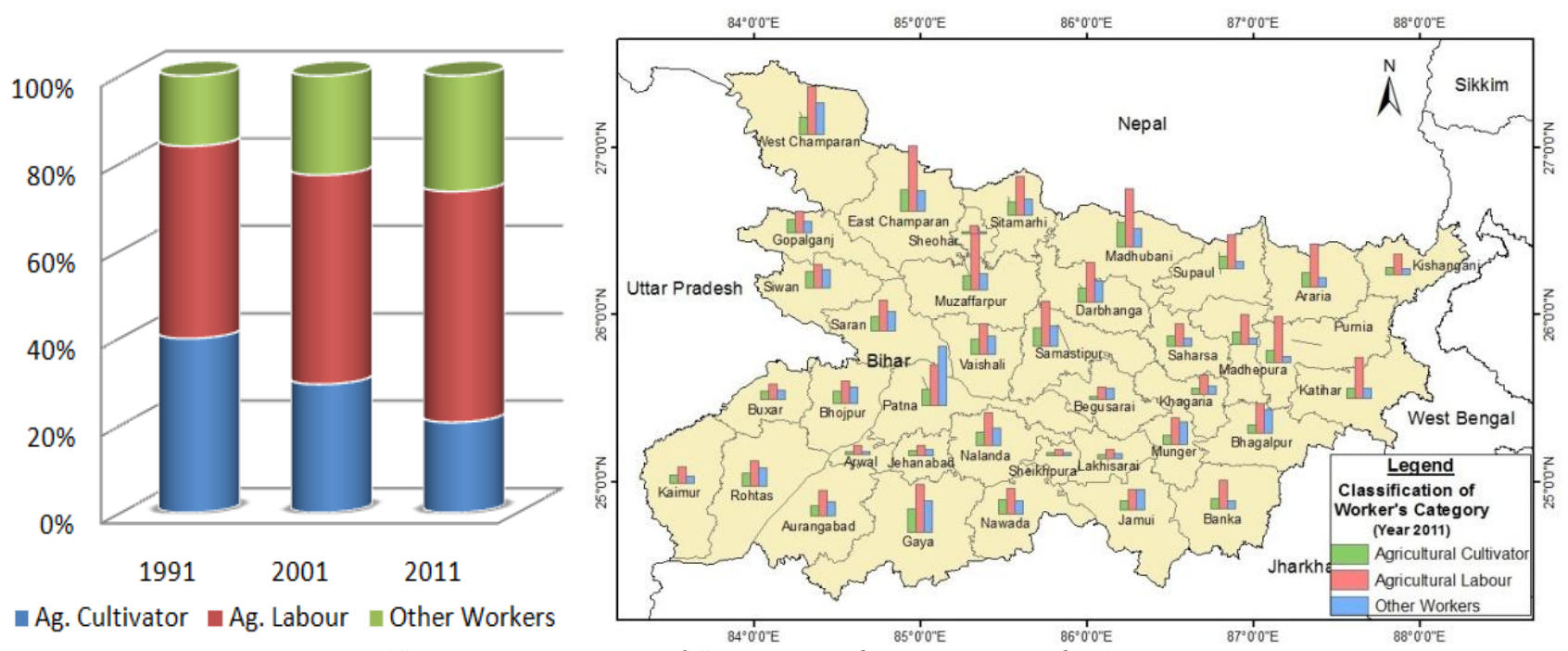

(Source: Directorate of Statistics and Economics, Bihar)

Figure 5:- (a) Classification of workers category in Bihar (b) District wise proportion of various workers category

In occurrence of flood, hectares of agricultural land get submerged and silted, which makes it uncultivable for few consequent years and remains as fallow field (Fig.6). A significant increase in fallow land can be visualised after 2008-09 which is the consequence of Kosi flood in year 2008. The area became uncultivable due to high silt deposition in the farm land. Several hectares of lands gets eroded and grains preserved by households gets destroyed which results into many small and marginal farmers becomes landless. Women from vulnerable families work as 
agricultural labour but due to flood this activity is completely stopped. Fig. 7 summarises the direct physical impacts of floods on agriculture sector.

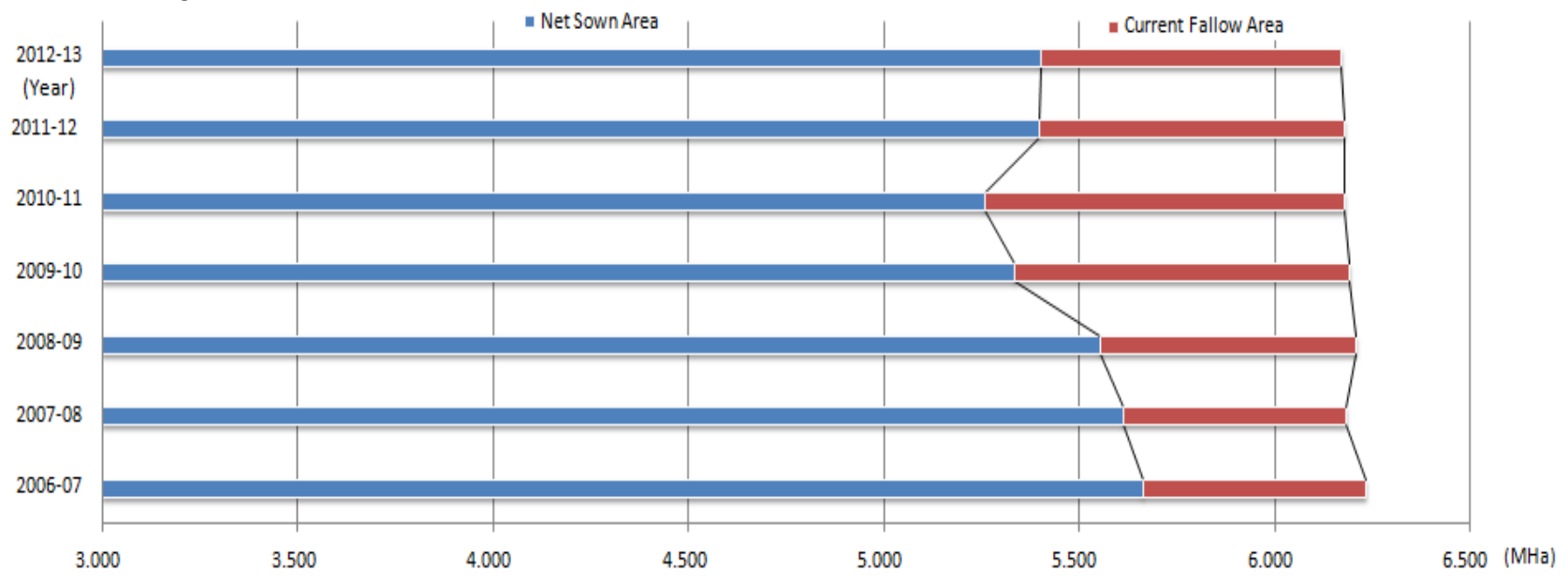

(Source: Directorate of Statistics and Economics, Bihar)

Figure 6:- Yearly variation in fallow area in Bihar

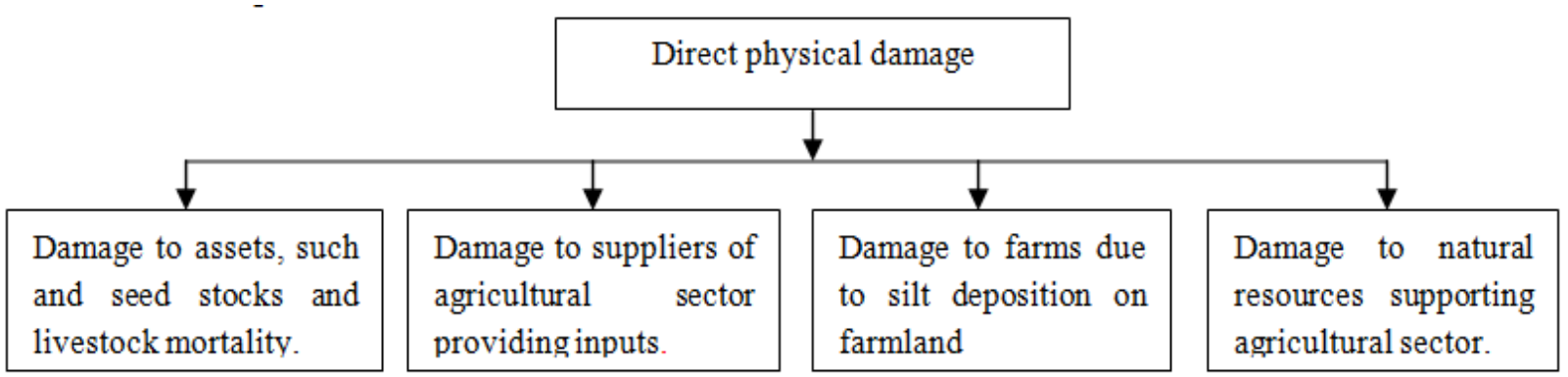

Figure 7:- Direct physical impact of flood on agricultural sector.

Generally the small cultivators as being on marginal level, takes agriculture inputs on credits from the local input dealers but due crop failure they are not in a position to re-pay these amounts. Further they do not remain in the position to manage for the next year and migrates in search of livelihood. This ultimately affects the agricultural production in consequents years also. Such adverse impacts of flood on agriculture badly affect the economy of state and its growth. These ill effects are shown in fig. 8.

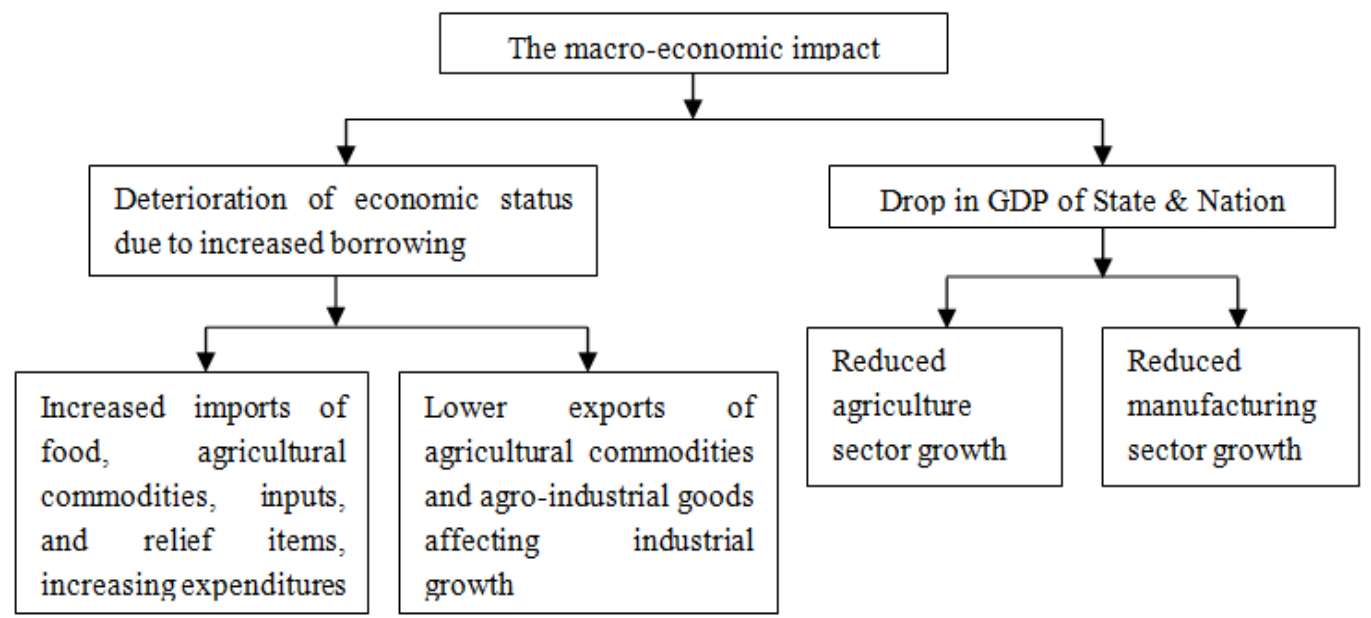

Figure 8:- Economic impact of poor agricultural growth. 
Due to recurrent flood events the miserable growth rate in agriculture and its allied services in Bihar for last one decade can be seen in fig. 9(a). As agriculture is the mainstay of Bihar's economy so poor growth in agriculture sector directly affects the GSDP of the state. Comparisons of Growth Rates (GNP of India \& GSDP of Bihar) are shown in fig.9(b). The overall GSDP of Bihar shows almost similar trend as that of GSDP in agricultural and allied sectors.

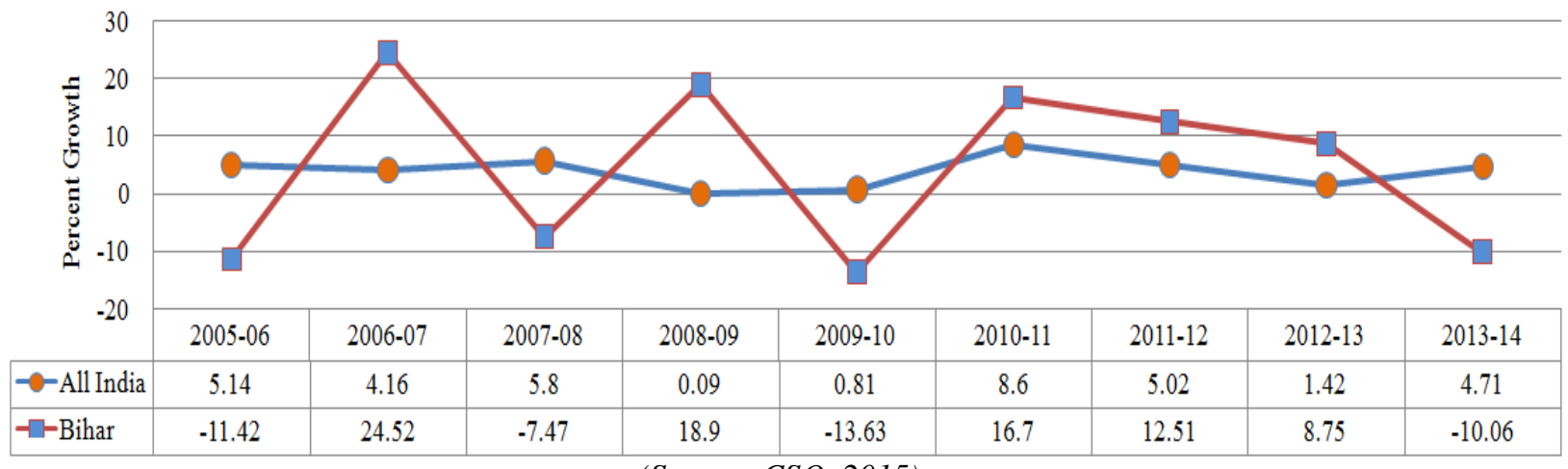

(Source: CSO, 2015)

Figure 9 (a):- Yearly Growth Rate (National and Bihar) in Agriculture \& Allied Sector

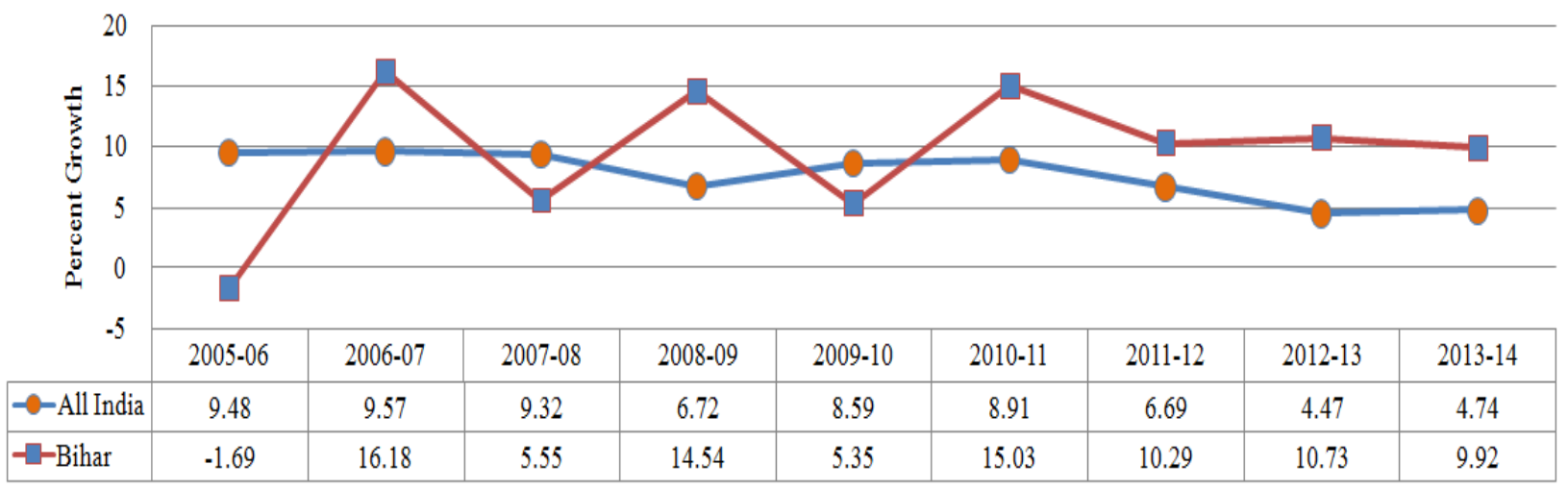

(Source: CSO, 2015)

Figure 9 (b):- Yearly Growth Rate (GNP of India \& GSDP of Bihar))

Next to agriculture sector which is contributing to NSDP of Bihar and equally affected by negative impacts of floods are industrial and manufacturing sector. These sectors are closely linked with infrastructure like power supply, water supply, communication, etc. In case of any disruption in these services, the production will be affected immediately. In event of flood, these services are affected primarily causing its consequence as temporary stoppage of production due to lack of electricity or water, disruption of raw material availability and inflow, temporary unavailability or shortages of labour, etc. During the flood, the industrial sector may confront damage that may include buildings, equipment and machinery, stocks of raw materials and of manufactured goods. In addition, after flood the sector may face changes in its production flows, including production decline and possible higher costs of production arising from the destruction of assets or other causes such as lack of raw materials, strategic inputs of water and electricity, temporary absence of labour, lack of working capital, etc. Furthermore, some branches of industry - such as the food producers - that rely on the production obtained from agricultural sectors for raw materials may suffer production declines even if no damage has happened to their facilities. In case of damage to building, equipment and machinery there is a need of funding to ensure returning the sector to its normal level of functioning or production. Fig. 10 shows the percentage growth or decline in various sectors in Bihar. Positive peak refers to potential of state whereas the negative fall shows the impact of flood during the year and its consequence. So flood is playing a vital role in miserable growth rate of state. Observation on growth rate in various sectors in last decade shows the highly unsustainable pattern. 


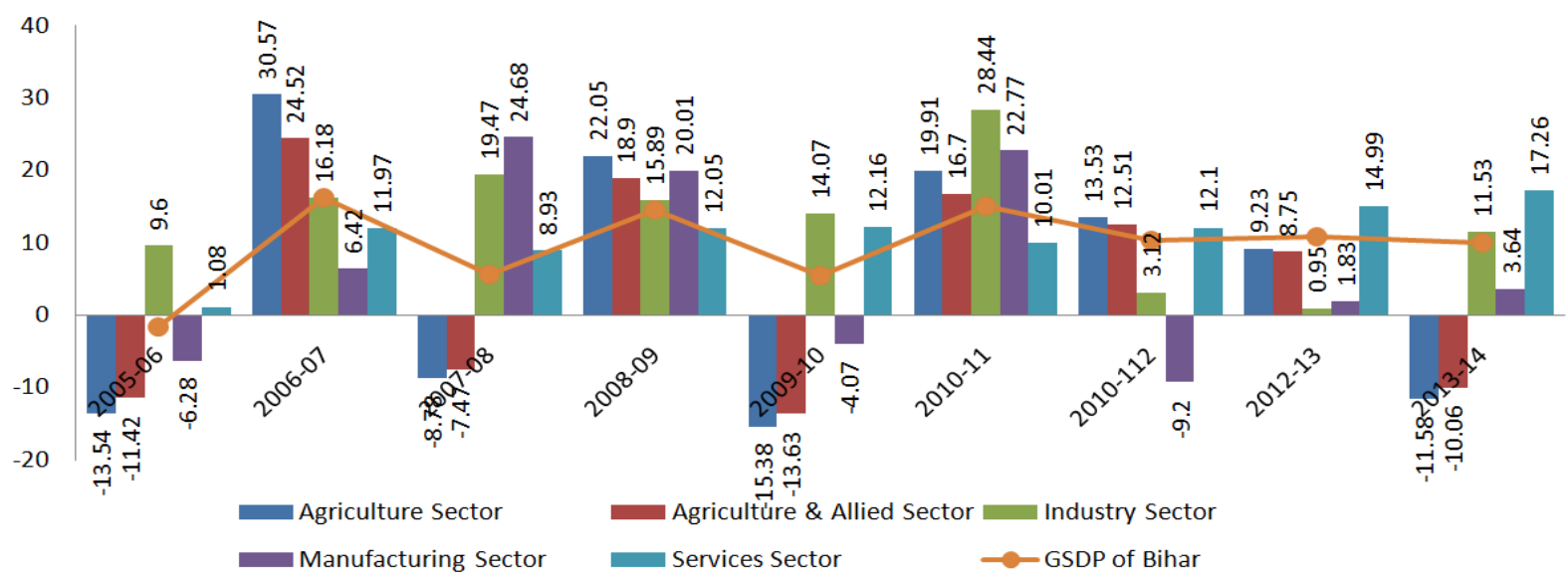

(Source: Directorate of Statistics and Economics, Bihar)

Figure 10:- Yearly Percentage growth rate in various sectors.

\section{Flood Management in Bihar:-}

In the above context, to minimize negative consequences and ill effects of flooding to maintain the sustainable growth of the state, there is a need of planning for flood management. As floods cannot be controlled completely so planning for flood management implies management of flood in such a manner to get maximum benefit in the given circumstances. Flood management measures can be broadly categorised in two types, (i) structural measures involving like construction of embankments, flood retention walls, flood levees, channel improvements, detention basins, and other such structural components whereas (ii) non-structural measures includes land use planning, redevelopment of flood prone areas, flood insurances, watershed management, flood forecasting, disaster mitigation and preparedness, etc. Both the measures are not mutually exclusive rather complementary to each other should be taken as integrated approach for best and effective result.

\section{Structural Measures:-}

In Bihar, mostly flood management works consists of constructing and maintaining the embankments (Fig.11). It comes under the category of short-term structural measures.

\section{Construction of flood embankments:-}

These are very popular structural measure adopted in the state not because of their efficacy but due to being cheap and quicker to construct. By March, 2013, a total of about $3732 \mathrm{~km}$ of embankments has been constructed and 1555 $\mathrm{km}$ is under construction which is scheduled to be completed by 2017 (WRD, Govt of Bihar, 2014).

\section{Channel improvements:-}

The existing embankments are under increasing pressure due to rise in the bed level of rivers due to heavy silts brought by the rivers from its upstream catchment area which lies in Nepal. It has been observed in Gandak that during the past three decades, the rise of bed level had been of the order of 1.8 meters approx. This type of aggradations necessitates perpetual raising and strengthening of the embankments. But this raising river bed levels, decreases their carrying capacity and causing drainage congestion in the countryside. To overcome such issues, method of improving the natural drainage or rivers by dredging and de-silting is a better option. It re-develops the carrying capacity of channels and enables it to flow at safe levels and within its banks. But this measure is not generally adopted due to its high cost of execution and others associated problems.

\section{Embankment protection works:-}

Embankment protection works are broadly classified in two categories, (i) Anti-erosion works and (ii) Floodfighting works. Anti-erosion works are carried out during the period of January to May every year for the restoration of embankments damaged during the flood period (monsoon months) due to excessive discharge in rivers and construction of any additional embankment protection structures like spurs, aprons, flood levees. Flood fighting works are carried out during flood period on need basis to protect the embankments during flood events. These are of emergent nature. 
In addition to above, it has also been observed so many times that creation of appropriate flood storage in reservoirs and detention basins will provide the long-term solution for the flood problems in the area. No such dam has been constructed either in Bihar or in Nepal on any of the tributaries of the Ganga which may provide flood moderation in the region. The major issue in this regard is there is no suitable site available in Bihar for dam building on any of the north Bihar Rivers as they originate from Nepal.
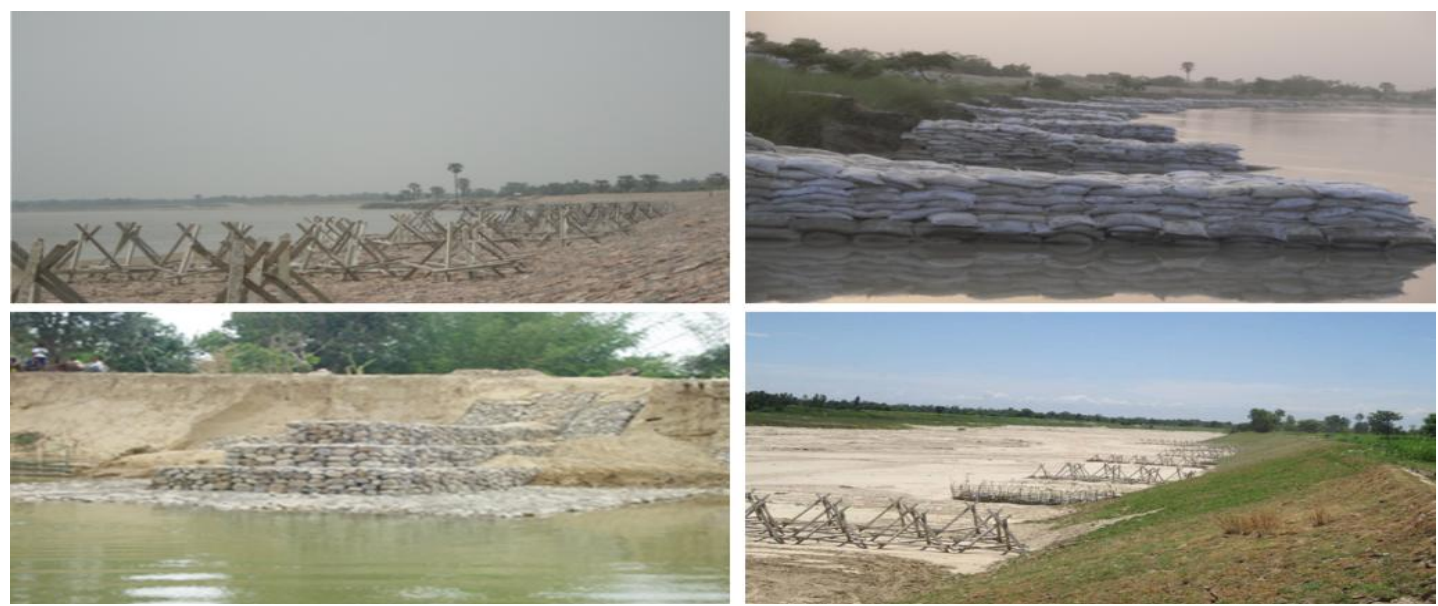

Fig 11:- Embankment and embankment protection works as structural flood control measure.

Hence, it is felt that structural measures itself is not sufficient to reduce the adverse impacts of floods in the state. There is need to adopt non-structural measures too as a judicious mix for effective flood management practices.

\section{Non-structural Measures:-}

But, losses in recent years contemplate that structural measure alone can't solve the problem. So it is felt necessary to adopt non-structural measure along with structural measures as an integrated approach to efficiently mitigate flood impacts. These non-structural measures includes,

\section{Land-use planning:-}

Use of land in flood prone area should be given consideration to master plan or governing laws. The land on a stream should be used for parks and recreational purposes, moreover as for ecological reserves. Infrastructures like washroom, picnic facilities etc. should be made flood proof. Private developments like golf courses may be brought up. The necessary purpose here is to integrate the land-use coming up with for flood-prone lands into the broader plans for the urban and surrounding space.

\section{Zoning of flood-prone lands:-}

To reduce flood damage in future the effective way is to prevent development in flood prone lands. So the best approach is zoning of such land, however the land use planning as discussed should be adopted so the land contains an outlined use. Zoning can be used to scale back damages from flooding and must be so flexible to acknowledge that different types of land use are compatible (Fig.12).

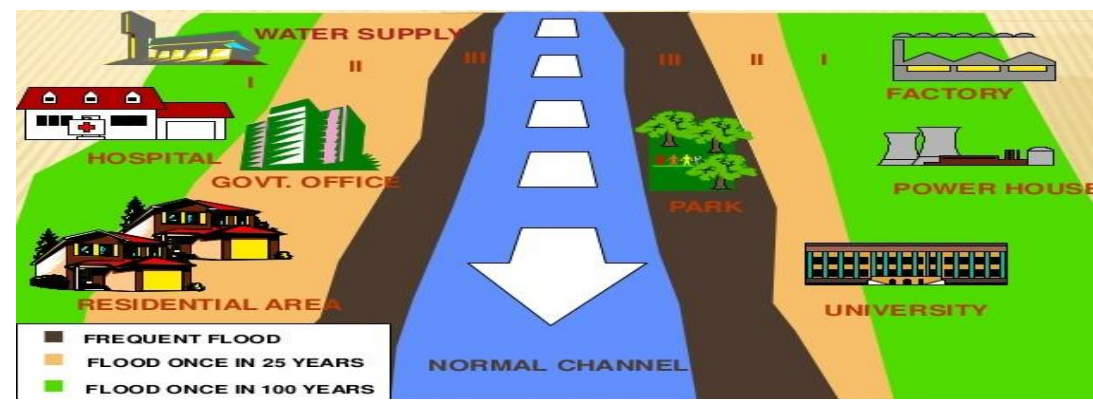

Figure 12:- Zoning of flood prone lands. 
As in flood prone areas having water velocities are low and not causing serious erosion, agricultural use of lands is acceptable. Particularly in case of Bihar, where agricultural land is limited so in view of self sufficiency in food supply, flood prone lands can judiciously be used as agricultural lands.

\section{Redevelopment of flood-prone areas:-}

A major flood disaster can be taken as opportunity to correct past planning errors. Removal of flood-prone development as well as conversion of the land to a defined and restricted use is an option to be considered. It should be more cost-effective in long run to physically relocate flood-prone development as a part of a disaster reduction programme.

\section{Compensation and incentives:-}

Compensation is provided to victims after the event of disasters. It helps them to restore their living up to some extent. But as part of disaster help, compensation must have a goal to reduce the future flood damages. So, instead to just paying for damage, the funds should be centred on flood proofing, buyouts and relocation to avoid recurrences of such events. Similarly, incentives should be developed to encourage flood proofing and relocations from flood prone areas. It should be supported through cost shared program having shares of government and owners as well.

\section{Flood Insurance:-}

Flood insurance works on the policy of distributing the losses among the wider segment of society. Peoples living in flood plains should be made aware regarding the flood insurance. The authority is needed to advice the peoples of the requirement of flood insurance and its benefits. Then in case of flood disasters, the losses of the affected peoples will be paid from the accumulated premiums of policy holders. So, flood insurance can be adopted as an important measure to reduce the flood impacts and its losses. "The Pradhan Mantri Fasal Bima Yojana" is an initiative in this regard but needs to be implemented more effectively and for all assets like livestock and livelihood in affected areas.

\section{Silt management:-}

The Lower reach of river Kosi and its contributing tributaries are severely affected floods every year. As the Kosi with its tributaries like Adhawara group, Bagmati and Kamla Balan originates from the hills and reaches to plains of Nepal Terai and Bihar, their flow velocity drops significantly. It results in increase of depth of flow and hence silt carrying capacity reduces. Due to reduction in water carrying capacity, silts get deposited (fig.13) at river bed resulting rise of river bed and consequently erosion of banks. The mouth of the channels oftenly gets obstructed and hence shifting of river course takes place taking new area under threat of flood. This development is additional attributed causing increase in the water level that ultimately results into overtopping and breaches of embankments and flooding within the basin. Therefore it needs watershed management with an effective silt management policy to resolve such issue.

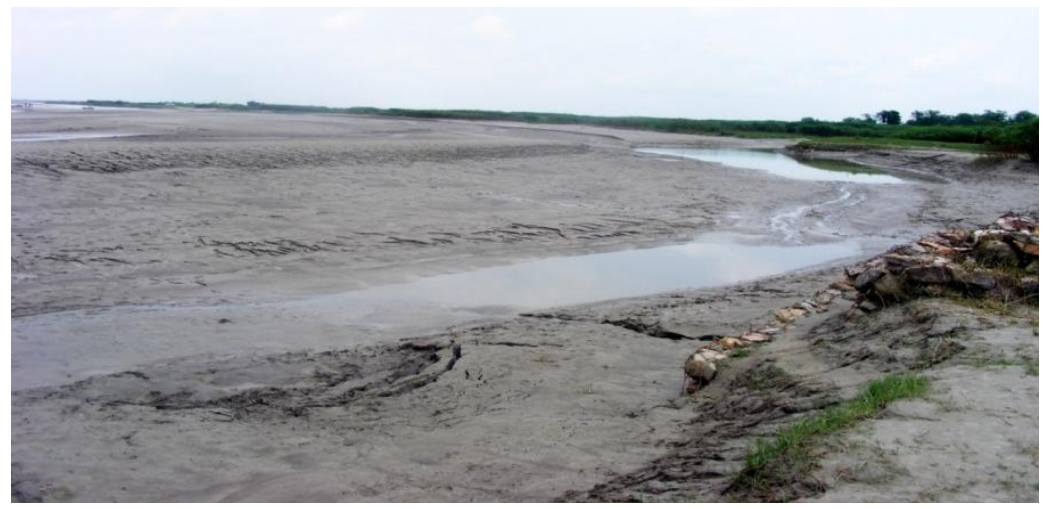

Figure 13:- Silt deposition in Kosi River at Saharsa.

\section{Flood forecasting and warning:-}

Flood forecasting and early warning system is a predominant non-structural flood protection measure. On the basis of mathematical modeling, experts can convert the past information like discharge, stage and inundation area from data base to present on the basis of rainfall, moisture and snow cover. For small catchments time lag between rainfall and peak flood is very small leading to flash floods. So quantitative precipitation forecasting and installing of radars is advisable in such areas. A framework for flood forecasting and warning system is shown in fig.14. In 
case of large rivers, it allows sufficient time for respond. Accurate forecasting is necessary as well as its formulation into reliable warning and effectively disseminated to the communities at risk to take necessary steps and reduce losses.

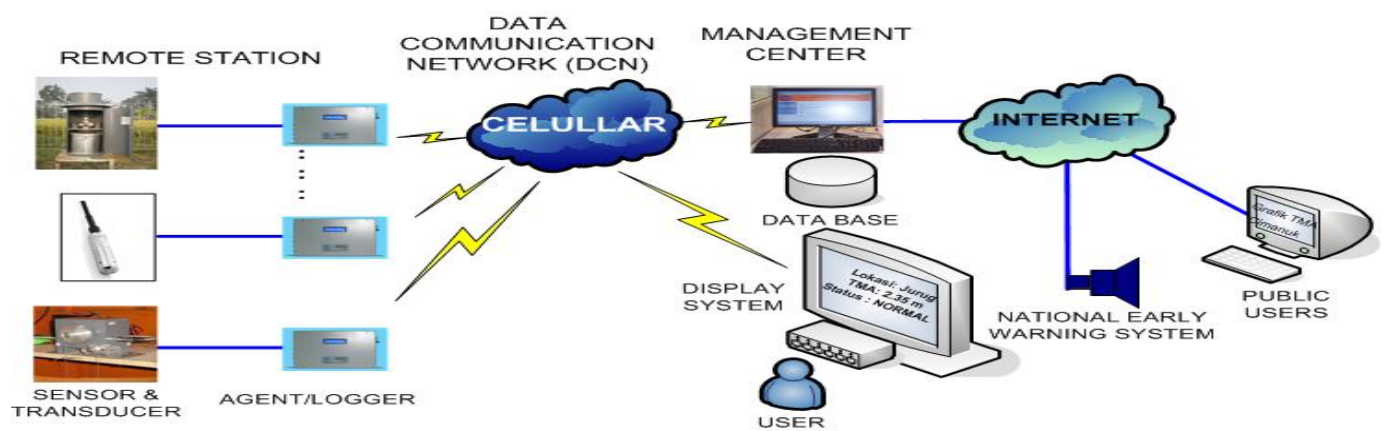

Figure 14:- Framework for flood forecasting and warning system.

\section{Conclusion:-}

Flooding is a perennial problem in the state of Bihar with devastating impact on the livelihood of people. The effects of damages to life and property caused by flooding were severe for several years. The damage to infrastructure also badly affects the industry sector. Agriculture is the mainstay to our large growing population and the back bone of state's economy playing primary role in its development. However, due to recurrent floods in the state, agriculture and allied sectors have accounted miserable growth rate but still play a vital role in the development of Bihar. It has been observed that flood events badly affect the agriculture sector and the GSDP of state in almost similar fashion. Majority of rural population belong to the lower socio-economic strata of the society. Small and marginal farmers, landless labour, and petty traders dominate the rural economy of the state, which suffers from extreme poverty conditions due to recurrent losses due to floods. In spite of the government's measures of flood management, households continue to live with suffering on an account of severe damage to their life and assets. It is not possible to avoid floods, but flood preparedness can be developed and its impact can be minimized. With appropriate planning and management, it is possible to reverse the uneven trend of growth in state and check the migration of the people in search of their livelihood. To minimize the negative consequences of flood impacts, flood management works so far implemented comprise of structural measures like, construction and maintenance of embankments, aprons in selected portions of river banks, land spurs and other necessary flood protection works. But structural measures alone cannot solve the problem. So there is need to adopt non structural measures as well. Nonstructural flood management measures such as land use regulations, flood forecasting and warning, flood proofing and disaster prevention, preparedness and response mechanisms should be adopted. The awareness of the community at risk of flooding should be raised and maintained with a clear understanding of their role in responding to emergency situations appropriately. They need to be developed so as to adaptation to the flood risk and living with them in flood plains and simultaneously permitting vacating the same for use by the river whenever the situation demands.

\section{References:-}

1. Central Statistical Organization (CSO) (2015) Ministry of Statistics and Programme Implementation, Government of India, New Delhi, <http://mospi.nic.in>

2. Directorate of Economics \& Statistics Department of Planning \& Development Government of Bihar (2013) Analysis of Budgetary Transactions of Bihar 2007-08 to 2011-12, Bihar, Patna

3. Directorate of Rice Development (2015) Rice in India - A Status Paper, Ministry of Agriculture \& Farmer's Welfare, Patna, Bihar < http://drdpat.bih.nic.in/>

4. Disaster Management Department Government of Bihar (2015) Annual Flood Damage Report, Bihar, Patna $<$ http://disastermgmt.bih.nic.in/>

5. Food and Agricultural Organisation of the United Nations (FAO) (2015) The impact of disasters on agriculture and food security, Rome, Italy

6. Gautam, K.P. and Hoek, E.E.(2003) Literature Study on Environmental Impacts of Flood, Delf Cluster Publication, June 2003

7. Gole, C. V. and Chitale, S. V. (1966) Inland delta building activity of Kosi river. Journal of the Hydraulics Division, American Society of Civil Engineers, v. 92, pp.111-126.

8. Government of Bihar (2016), Bihar Economic Survey-2015-16, Ministry of Finance, Patna, March, 2016 
9. Institute of Applied Manpower Research (2011) India Human Development Report 2011: Towards Social Inclusion, Planning Commission, Government of India, New Delhi.

10. Kansal, M.L., Kishore, K.A. and Kumar, P. (2016) Flood Impacts and Its Management in Bihar, $32^{\text {nd }}$ National Convention of Civil Engineers on Role of Civil Engineers in Sustainable Development of India, Goa, October 21-22, 2016

11. Kansal, M.L., Kumar, P. and Kishore, K.A. (2016) Need of Integrated Flood Risk Management (IFRM) in Bihar, National Conference on Water Resources and Flood Management with Special Reference to Flood Modeling, Surat, October 14-15, 2016

12. Kansal, M.L., Kishore, K.A. and Kumar, P. (2016) Impact of Floods on Sustainable Development and its Management in Bihar, $31^{\text {st }}$ Indian Engineering Congress, Kolkata, December 16-18, 2016

13. Kumar, D. (2015) International Water Resources Association, XVth World Water Congress, Edinburgh, Scotland, May 25 - 29, 20015

14. National Disaster Management Authority (2008) Government of India, National Disaster Management Guidelines, Management of Floods, New Delhi, India

15. Reserve Bank of India (2015) Handbook of Statistics on Indian Economy 2014-15, Reserve Bank of India, New Delhi <https://www.rbi.org.in/scripts/ AnnualPublications.aspx> (Sep. 16, 2015).

16. Sinha, C.P. (2008) Economic \& Political Weekly, Management of Floods in Bihar, New Delhi, November 15, 2008

17. Sinha, R., Burton, M., and Tiwari,. G. (2012) Strengthening the Institutional Framework for Flood and Water Management in Bihar, International Growth Centre, London

18. United Nations (1992) "Declaration of the 1992 Rio Conference on Environment and Development", Rio de Janeiro, Brazil, April 1992

19. Water Resources Department (2013) Flood Report 2013, Flood Management Improvement Support Centre (FMISC), Water Resources Department, Government of Bihar, Patna, <http://fmis.bih.nic.in/ publications.html> (2013). 